The Imprisonment of Women in South East Asia: Trends, Patterns,

Comparisons and the Need for Further Research

\author{
Dr. Samantha Jeffries \\ School of Criminology and Criminal Justice \\ Griffith University \\ 176 Messines Ridge Road, Mount Gravatt \\ Queensland, Australia 4122 \\ E-mail: s.jeffries@griffith.edu.au \\ Telephone: +61 737351120 \\ Fax: +61 737355608
}




\title{
The Imprisonment of Women in South East Asia: Trends, Patterns, Comparisons and the Need for Further Research
}

\begin{abstract}
Using extant data this paper describes and compares trackable variations in the imprisonment of women over the last couple of decades across eight South East Asian countries including: Cambodia, Indonesia, Vietnam, Thailand, Singapore, the Philippines, Malaysia, and Myanmar. Aside from Myanmar, preliminary observations suggest increases in women's prisoner numbers, rates and share of those incarcerated with growth corresponding but generally outstripping that found for men. Comparatively speaking, Thailand, Vietnam, and Singapore ranked highly on measures of women's incarceration and growth while Malaysia scored at the lower end of the scale. Growth in the imprisonment of women is especially high in Indonesia and Cambodia whereas Myanmar is characterised by the high use of imprisonment for women but minimal growth. Elucidating these results was complicated by a distinct dearth of reliable data and/or regionally specific research pertaining to the imprisonment of women in the relevant nation-states. Limited information available in three jurisdictions (Thailand, Cambodia and Malaysia) suggests that policy changes, alongside shifting criminal justice system responses to particular types of crime, could be driving upward trends and disproportionately impacting on the imprisonment of women. In conclusion, it is argued that there is a pressing need for both country specific and crossregional research on the incarceration of women in South East Asia.
\end{abstract}

\section{Key Words:}

Women, Imprisonment, South East Asia. 


\section{Introduction}

Throughout history, women prisoners have been "correctional afterthoughts", they are often ignored because of their small numbers, making them a relatively 'invisible' or 'forgotten' population (Chesney-Lind 1998; Covington 2008; Fletcher, Shaw and Moon 1993; McQuaide and Ehrenreich, 1998). The disproportionate over-representation of men in prison has resulted in the development of prison systems by men for men with women's experiences invariable subsumed and subsequently pre-conditioned by normative male assumptions (Braithwaite, Treadwell and Arriola 2005; Fair 2009, p.3; Gainsborough 2007, p.271). Yet women prisoners are not, at least numerically speaking, as 'invisible' as they once were. Over the last couple of decades, the number of women incarcerated in Western nations (particularly in the United States) has been dramatically increasing (Greene and Pranis 2006; McIvor 2010). As observed by McIvor (2010, p.557):

One of the most striking phenomena in recent years has been the dramatic increase in western jurisdictions in the numbers of women imprisoned, resulting in female prison populations reaching unprecedented levels

Upward trends in numbers of women imprisoned has resulted in extensive discussion, analyses and scholarly debate within western feminist criminology particularly in the United States and United Kingdom (e.g. see Chesney-Lind and Pasko 2004; Gelsthorpe 2006; Hedderman 2004; Hedderman 2012; Kruttschnitt and Gartner 2003; Mauer, Potler and Wolf 1999; Bush-Baskette 1998; McIvor and Burman 2011).

Concern about the incarceration of women in the United States is perhaps unsurprising given that more women are imprisoned there than anywhere else in the world (Hartney 2006, p.5; Walmsley 2012, p.3). Between 1990 and 2000, the number of women imprisoned doubled increasing from around 80,000 to 160,000 . By 2010 , almost 113,000 women in the United 
States were under the jurisdiction of state and federal correctional authorities and over 92,000

were held in local jails - a total of some 205,000 (Walmsley ${ }^{1}$ personal correspondence, 2013). In addition, women's share of the total prison population and incarceration rates have swelled (Chesney-Lind 1998, p.1). Between 1997 and 2011, the proportion of inmates who were women increased from $6.4 \%$ to $7.4 \%$ and from 1997 to 2010, women's imprisonment rates grew from 54 to 67 per 100,000 (Chesney-Lind 1998, p.1; U.S. The Sentencing Project 2011, p.3-4; Department of Justice 2010).

Similar increases in the incarceration of women have been noted in other western jurisdictions including the United Kingdom, Australia and New Zealand. Between 1992 and 2009, the average number of women who were incarcerated in the United Kingdom increased from 1,577 to 4,300 and the percentage of women incarcerated rose from 3.4 to $5.1 \%$ of the total prison population (McIvor 2010, p.558). In 1995, the number of women incarcerated in Australia totalled 835 and by 2012, this number had reached 2,201. Women's share of total prisoner numbers also increased from $4.8 \%$ to $7 \%$, and rates of incarceration grew from 12 to 25 per 100,000 (Australian Bureau of Statistics 2013, p.9-10; Gelb 2003, p.3-4). In New Zealand, the number of women imprisoned more than doubled from $1997(n=206)$ to 2006 $(n=429)$ and the proportion of incarcerated women increased from $4.0 \%$ to $5.7 \%$ (Morrison, Soboleva and Chong 2008, p.114).

Research suggests that this vertical trending in western women's imprisonment has more to do with determinedly incremental modifications to (western) criminal justice policy towards, arguably, more resolutely punitive rationales - than any sudden transformation in the nature of (western) women's offending. In the United States feminist scholars theorise that

\footnotetext{
${ }^{1}$ World Prison Brief Director, International Centre for Prison Studies.
} 
determinate and mandatory sentencing in conjunction with 'war on drugs' policies are the key drivers of this growth. Indeed, certain parties have stridently argued that these initiatives have had a large and disproportionate impact on women (Bloom, Owen and Covington 2004, p.3940; Covington and Bloom 2003, p.5; Kruttschnitt 2010, p.33; McIvor 2010, p.560; Mauer, Potler and Wolf 1999, p.2). If compelled to generalise it could be suggested that the United States criminal justice system has become less lenient at all levels of decision making and in regards to all categories of crime including - but not limited to - those comparatively trivial offences, such as petty property crime and drug use, traditionally considered to be the ‘domain of women' (McIvor 2010, p.560).

In the United Kingdom, it is similarly purported that, "the criminal justice system's response to women seems to be changing as much if not more than women's underlying behaviour" (McIvor 2010, p.561). Such readings are productive inasmuch as they insist that everincreasing rises in women's imprisonment are more productively understood as the effects of on-going modifications to sentencing legislation (e.g. determinate sentencing, harsher penalties for drug offending) than as measured judicial responses to a tangible increase in the seriousness of women's offending. There is now sufficient evidence to suggest that harsher sentencing climates tend to generate disproportionately harsher penalties for comparatively minor crimes which are typically associated with women. Hence, the types of crimes women customarily commit are now more likely to result in prison sentences and longer incarceration terms (McIvor 2010, p.562).

Compared to the United States and United Kingdom there is little analyses of changes to imprisonment trends for women in the Australasian region. Preliminary analyses drawn from the New Zealand context tend to suggest that growth is once again not strongly correlated 
with an increase in the seriousness of offences committed by women (McIvor 2010, p.563).

Contrastingly, increases in the imprisonment of women within Australia have been correlated with both the nature and seriousness of offences for which Australian women have been ordered to serve a custodial term, with Gleb $(2003$, p.7) reporting increases in the proportion of women prisoners sentenced for more serious types of violent crime.

An interesting question is whether or not upward trends in the imprisonment of women are confined to the western experience? We know, for example, that in many South-East Asian countries overall prison populations have increased significantly over the last few decades but whether or not this vertical trending has impacted on women's prison populations has yet to be ascertained (see data compiled by the International Centre for Prison Studies available at http://www.prisonstudies.org/). We also know that compared to western nations, women in many South East Asian countries constitute larger proportions of overall prisoner numbers. Women in "about $80 \%$ of prison systems worldwide comprise between $2 \%$ and $9 \%$ of the total prison population". Only twelve prison systems have higher percentages than this, only one of these is a western country (the Netherlands) and five are in South East Asia (Thailand, Vietnam, Singapore, and Lao) (Walmsley 2012, p.1). This means that from a numerical stand-point women incarcerated in South East Asia are more visible than their western counterparts. Yet to date, there have been no systematic analyses of changes in the incarceration of women in South East Asia over-time.

The purpose of this paper is to describe, compare and (at best) tentatively explore using the extant research explanations for patterns and trends in the imprisonment of women across South East Asia over the last couple of decades. It is also hoped that these analyses and the 
relative paucity of research/data available to elucidate them further will generate a sense of urgency with regard to the need for future research in the region.

\section{The Current Analyses}

The measures utilized in the following analyses to identify patterns and trends in the imprisonment of women in South East Asia include: 1) prisoner numbers, 2) proportion of women in prison, 3) imprisonment rates and, 4) female to male rate ratios. Each of these measures captures a different facet of the extent of the imprisonment of women and how it may have changed over time. Used together, these measures also provide a tentative basis from which to compare trends and patterns between countries (Greene and Pranis 2006, p.17).

Data for the analyses derives from an international prison statistics archive which has been compiled by Roy Walmsley, the Director and Manager of the World Prison Brief for the International Centre for Prison Studies http://www.prisonstudies.org/info/worldbrief/wpb_about.php). The World Prison Brief contains data on prison systems throughout the world. Prisoner numbers (comprising inmates who were both sentenced and on remand $)^{2}$ by sex (male and female) ${ }^{3}$, country and year were supplied to the author by Roy Walmsley on behalf of the Centre. ${ }^{4}$ Data availability limited the current analyses to eight South-East Asian countries over the following years or study periods:

\footnotetext{
${ }^{2}$ Data by sex and prisoner status (i.e. sentenced versus remanded) was unavailable.

${ }^{3}$ Includes both children and adults.

${ }^{4}$ The World Prison Brief is recognised as being a unique source of world prison population information, based on official information from national prison administrators, the government Ministries responsible for prisons and the national statistical offices. It is widely used by international bodies (including the United Nations), governments, prison authorities, academics and other criminal justice experts. The collation of prison data into a reliable data source provides a unique opportunity to assess differences in the levels of imprisonment across the world, including South East Asia. The World Prison Brief is obviously restricted, however, by the data recorded by nation states. Thus, there is some variability in dates and data 'break downs' by gender and other potentially important factors (e.g. age, ethnicity, race, immigration status) are frequently missing or simply unavailable.
} 
- Thailand - 1993-2012

- Vietnam - 1998, 2005-2007, 2009-2012

- Philippines - 2001-2002, 2005-2006, 2009-2012

- Myanmar - 2001-2002, 2007-2009, 2011

- Indonesia - 1993-2005, 2008-2012

- Malaysia - 1994-2012

- Cambodia - 1994-2012

- Singapore ${ }^{5}-1993-2012$

\section{Prisoner Numbers}

In 2012, Thailand $(n=37,790)$ had the largest number of women incarcerated followed by Vietnam $(n=16,350)$, the Philippines $(n=8,464)$, Indonesia $(n=7,687)$, Malaysia $(n=2,113)$, Cambodia $(n=1,266)$ and, Singapore $(n=1,230)$. While 2012 figures for Myanmar were unavailable, 8,000 women were incarcerated in this country in 2011.

Using the first year of each country's study period as a base-line referent, one could reasonably assert that the number of women imprisoned grew significantly in all countries with percentage increases outpacing men in every nation aside from Myanmar. The number of women in prison grew from between 36\% (in Myanmar between 2001 and 2011) and 1261.3\% (in Cambodia between 1994 and 2012). Overall percentage increases in men's numbers were lower than for women ranging from 60.4\% (in Singapore between 1993 and 2012) to 630.0\% (in Cambodia between 1994 and 2012) (see Figure 1).

[Insert Figure 1, Here]

\footnotetext{
${ }^{5}$ Singapore figures need to be read with a degree of caution because persons in Drug Rehabilitation Centres and those on community-based programmes are included in some years but not in others.
} 


\section{Proportion of Women in Prison}

Given the above trends in prisoner numbers by sex it is unsurprising that women's share of total prison numbers increased in every country except Myanmar. Comparisons of the first and last years in each respective country's study period show that the proportion of women in prison nearly trebled in Singapore $(1993=3.3 \%, 2012=9.8 \%)$ and more than doubled in Thailand $(1993=7.7 \%, 2012=15.9 \%)$, Vietnam $(1998=5.5 \%, 2012=12.6 \%)$ and Indonesia $(1993=2 \%, 2012=5.1 \%)$. Increases were also evident in the Philippines $(2001=5.3 \%$, 2012=8\%), Cambodia $(1994=4.7 \%, 2012=8.4 \%)$ and Malaysia $(1994=4.1 \%, 2012=5.8 \%)$. In Myanmar the proportion of women in prison decreased from $19.1 \%$ in 2001 to $12.1 \%$ in 2011 (see Figure 2).

Over the years for which data was available, Myanmar had the largest average percentage of women in prison $(m=14.8 \%)$, followed closely by Thailand $(14.1 \%)$. The proportion of women incarcerated in Thailand peaked in 2004 at $21.7 \%$ of the total prisoner population, reduced from 2005 to 2009 before trending upwards between 2010 and 2012. Women's share of total prison population numbers in Myanmar was at its highest in 2001 sitting at $19.1 \%$ and reduced thereafter.

Vietnam $(m=11.0 \%)$ had the third highest average proportion of women in prison with the percentage peaking in 2012 at $12.6 \%$ followed by Singapore $(m=8.3 \%)$, the Philippines $(m=7.3 \%)$, Malaysia $(m=6.1 \%)$ Cambodia $(m=5.6 \%)$ and Indonesia $(m=4.0 \%)$. In Singapore the proportion reached its highest percentage point in 2006 (13.4\%) and subsequently declined. In the Philippines, percentages increased substantially between 2001 and 2005 and have since lingered at around the 8\% mark. In Indonesia and Malaysia, proportions of women 
in prison were at their height in $2008(7.9 \%)$ and $2010(10.0 \%)$ respectively but have since reduced. In Cambodia the proportion of total prisoner numbers constituted by women increased steadily from 2007 peaking in 2012 at $8.4 \%$ (see Figure 2).

\section{[Insert Figure 2, Here]}

\section{Imprisonment Rates}

The above calculations rely on prisoner numbers and are affected by population differences between and changes within countries. Imprisonment rates ${ }^{6}$ remove the effect of population variance and rate ratios, which are calculated using these rates, ${ }^{7}$ can provide a useful picture of the gaps by sex over time and across countries. Calculations of rates (and thus rate ratios) required Estimated Resident Populations figures which are available from the United Nation's (2010) World Population Prospects. However, these data were only available up to 2010 meaning that rates (and subsequent rate ratios) could not be calculated for later years.

Removing the effect of population size, across the study periods Thailand ( $m=77.7)$ had the highest average rate of incarceration for women per 100,000. This was followed by Singapore $(m=53.2)$, Myanmar $(m=31.5)$, Vietnam $(m=23.8)$, Malaysia $(m=17.4)$, the Philippines $(m=14.0)$, Cambodia $(m=5.6)$ and Indonesia $(m=3.0)$ (see Figure 3).

[Insert Figure 3, Here]

\footnotetext{
${ }^{6}$ Imprisonment rates are calculated as follows: number of prisoners (male or female) / Estimated Resident Population (male or female) x 100,000.

${ }^{7}$ Rate ratios are calculated by dividing a male and a female rate.
} 
As illustrated in Figure 3, the rate of incarceration for women increased steadily in Thailand over the 1990's peaking in 2002 (146.8 per 100,000) and declining thereafter. By 2006, these rates had more than halved $(68.3$ per 100,000) dropping to a low of 65.9 in 2009 before increasing to 83 per 100,000 in 2010 . Singapore similarly recorded rapid increases over the 1990's with rates of imprisonment for women peaking in 2003 (99.7 per 100,000), more than halving by 2008 (44 per 100,000) and increasing again, but only slightly in subsequent years.

Rises and ensuing apexes in imprisonment rates for women were somewhat delayed in the remaining countries. In Cambodia rates were fairly stable through the 1990's but more than doubled between 2004 (5.1 per 100,000) and 2010 where the rate hit its highest point of nearly 12 per 100,000. Indonesia witnessed rapid increases in the rate of women's imprisonment between 2003 (2.6 per 100,000) and 2008 (9.2 per 100,000). Myanmar and Malaysian rates were at their highest in 2007 (41.0 and 36.9 per 100,000 respectively). Since these peaks, rates in Indonesia, Myanmar and Malaysia appear to be in general steady decline. Available Vietnamese data show a significant increase between 1998 (7.6 per 100,000) and 2005 (26 per 100,000) but little change thereafter. The rate of women's imprisonment in the Philippines increased from 9.3 to 16.6 per 100,000 between 2002 and 2005 but then proceeded to stabilise which is notably in keeping with other similarly observed trends in the region (See Figure 3).

As illustrated in Figure 3, trends in imprisonment rates for women generally paralleled those for men. However, overall increases exceeded those for men in every country aside from Myanmar. Using the imprisonment rate in the first year of each country's study period as the base-line, the overall rate of women's incarceration grew from between $0.8 \%$ (in Myanmar between 2001 and 2009) and 643.8\% (in Cambodia between 1994 and 2010) (see Figure 4). 
[Insert Figure 4, Here]

These trends were persistent, with average percentage growth in the rate of women's imprisonment (i.e. mean percentage increases across the years for which data was available) exceeding those of men in Thailand, Vietnam, the Philippines, Indonesia, Malaysia, Cambodia and Singapore. In Myanmar the average percentage increase in the imprisonment rate for men was higher than for women (see Figure 5)

[Insert Figure 5, Here]

\section{Female to Male Rate Ratios}

Comparative female to male rate ratio data evidences trends that appear to affirm the prior data on the proportions of women in each country's total prison population. Rate ratios were on average narrowest in Myanmar and Thailand with incarceration being 5.9 and 7 times less likely for women than men. Thai ratios were at their minimum in 2004 when imprisonment was only 3.7 times less likely for women. This widened between 2005 (ratio=4.9) and 2009 (ratio=8.5) before decreasing again in 2010 (ratio=6.1). In Myanmar female to male rate ratios were lowest in 2001 (ratio=4.3) and broadened thereafter before reaching 8.6 in 2009 (see Figure 6).

[Insert Figure 6, Here]

Vietnam recorded the third narrowest average rate ratio gap with women 9.6 times less likely to be imprisoned than men. Vietnamese rate ratios approximately halved across available 
years. In 1998, women in Vietnam were 18 times less likely to be in prison than men and ratios reduced thereafter to between 7.3 and 9.4. In the Philippines the average rate ratio was 13.5 and once again, the female to male rate ratio diminished over time. In 1998, women in the Philippines were 17.7 times less likely to be imprisoned than men but in proceeding years this reduced to just over 11 (see Figure 6, above).

Singapore had the fifth lowest average rate ratio (ratio=16.0) of female to male imprisonment followed by Cambodia (ratio=18.7), Malaysia (ratio=20.5) and Indonesia (ratio=31.4). In 1994, women in Singapore were over 50 times less likely to be incarcerated than their male counterparts. Over the preceding 12 years this female/male gap narrowed markedly, falling to around six in 2006 before increasing slightly between 2007 and 2010. Similarly, the 1996 Malaysian rate ratio was over 30, by 2003 it had reduced to 9.8 but showed a marginal increase in subsequent years. For Indonesia the largest gap between sexes occurred in 1997 at which time women were 56 times less likely than males to be imprisoned; by 2008 the gap had contracted to 11.7 before widening to a little over 16 in 2009 and 2010. Rate ratios in Cambodia fluctuated over time but generally trended downwards. Cambodian women went from being around 20 times less likely than men to be incarcerated at different points in time to 16.1 times less likely in 2010 (see Figure 6, above).

\section{National Comparisons}

Table 1 (below) summaries the data reported above by country across the measures used to assess patterns and trends in the imprisonment of women including: numbers, proportions, rates and, rate ratios. Thailand, Vietnam and Singapore rank comparatively highly on these measures while Malaysia's score is relatively low. Growth in the imprisonment of women is 
especially high in Indonesia and Cambodia whereas Myanmar is characterised by a high use of imprisonment for women but minimal growth.

\section{[Insert Table 1 Here]}

In 2012, Thailand had the largest number of women in prison, the highest rate of incarceration for women and devoted a substantial share of prison places to women. Yet comparatively speaking the growth in imprisonment numbers and incarceration rates for women has not been as pronounced. This likely reflects significant downward trends in the imprisonment of Thai women over the last decade.

Vietnam ranks among the top four on every scale of women's imprisonment. After Thailand, Vietnam had the largest number of women prisoners in 2012. The 2010 rate of imprisonment for women placed third while the average rate ranked fourth. Further, Vietnam had the largest average and third greatest increase in incarceration rates for women over the study period. Ranking third in average proportions of total prisoner population, Vietnamese women also constituted the second largest share of 2012 prison places and ranked highly on rate ratio measures.

In Singapore rates of incarceration for women - on average and in 2010 - ranked second, after Thailand. Measurable growth in incarceration rates for women in Singapore - overall and average - ranked fourth while expansion in the number of women in prison placed fifth. Comparisons with the imprisonment of men showed that Singaporean women constituted the fourth largest proportion of inmates on average and in 2012. Further, in 2010 male/female rate ratios ranked third while average ratios placed fifth. 
In Indonesia and Cambodia the number of women in prison, incarceration rates for women, male/female rate ratios and women's share of total prison prisoner numbers were all comparatively low. However, growth in the imprisonment of women in both nations was relatively high. Cambodia ranked first and Indonesia second in prisoner number and overall imprisonment rate growth. Indonesia also placed second for average percentage increases in incarceration rates for women while Cambodia ranked fifth.

Compared to the other countries analysed, women in Myanmar are incarcerated in fairly high numbers, at comparatively high rates, constitute significant proportions of the prison population and rank highly on rate ratio measures. However, compared to the other South East Asian nations, there was minimal growth in the incarceration of women with Myanmar ranking eighth in prisoner number growth and increases in incarceration rates for women (overall and average).

Malaysia's position across the measures fell near the bottom of the scale - rankings ranged from five to seven. Comparatively speaking, in 2012 few women were imprisoned in Malaysia and imprisonment rates - average and overall - were minimal. Growth in the number of women imprisoned and rates of incarceration for women were also relatively negligible and the number of prison places devoted to Malaysian women fell at the lower end of the scale.

\section{Discussion - Exploring Possible Explanations for Growth in the Imprisonment of} Women 
The analyses presented in this paper indicate growth has been a defining feature in the imprisonment of women in most South East Asian jurisdictions over the last few decades. The question that remains unanswered is what factors are driving this trend? In western contexts it has been erroneously assumed that significant shifts in the fundamental nature of women's offending were responsible for similar growth in women's incarceration but research has all but rejected this thesis. Rather it is argued that changes in western criminal justice system responses to women's criminality alongside legislative and policy changes have disproportionately impacted on women (e.g. the 'war on drugs' in the U.S.) (McIvor 2010, pp. 564).

Discounting the possibility that a fundamental shift in the calibre and condition of women's criminality in the South East Asian context is responsible for the above reported trends in the imprisonment of women in this region is problematized by a pronounced dearth in the data and research required to contradict such a proposition. There is also a general lack of research on nation and region specific criminal justice system responses to women. Nonetheless, available information from three countries (Thailand, Cambodia and Malaysia) suggests that legislative and crime/criminal justice policy change and subsequent responses to particular types of offending could be driving upward trends and disproportionately impacting on the imprisonment of women.

In general, increases in Thai of inmate populations from the late 1990's until 2002 is attributed to the Thai government's "shift to a more prioritised crackdown on narcotics in the late 1990's" (Kittayarak 2010: 153). Not dissimilar to the 'war on drugs' in the United States, the Thai government's crime control/law enforcement approach resulted in drug offenders of 
"whatever nature being indiscriminately imprisoned" (Junlakan, Boriboonthana and Sangkhanate 2013, pp. 317).

Between 2002 and 2007 three key responses led to a reduction in Thai imprisonment including: 1) the release of prisoners under Royal Pardon, 2) the implementation of the Narcotic Addict Rehabilitation Act 2002 which essentially decriminalised drug abuse and diverted drug users away from the criminal justice system and into treatment, 3) the use of non-custodial sentencing alternatives (i.e. expansion of probation and community-based treatment programs) (Junlakan, Boriboonthana and Sangkhanate 2013, pp.317; Kittayarak 2010, pp. 155-160; Pearshouse 2009, pp. 3).

Nonetheless, between 2006 and 2010 the numbers of drug-related arrests in Thailand rose sharply while the number of other offences decreased. The substantial increase in drug arrests correlates with the criminalization of new substances including methamphetamine, the reintroduction of more stringent drug control policies, government directives urging a more proactive law enforcement stance toward the supply and demand of illicit drugs (Junlakan, Boriboonthana and Sangkhanate 2013, pp. 317-318). Rises in drug arrests subsequently drove overall increases in police recorded crime. Longer imprisonment terms also started to be imposed on major drug offenders. Combined, these changes in policy and criminal justice system practice may explain more recent upward trends in Thai incarceration (Junlakan, Boriboonthana and Sangkhanate 2013, pp. 318). Indeed, as of 31 January 2012 nearly 63\% $(n=104,722)$ of all incarcerated offenders were serving time for drug crimes (Junlakan, Boriboonthana and Sangkhanate 2013, pp. 317-318). 
Unfortunately, there is limited published data and commentary on how the above changes in criminal justice system responses, legislation and policy have specifically impacted the incarceration of Thai women. It is reasonable to assume that the release of prisoners under Royal Pardon, decriminalisation of drug abuse and the expansion of community based sanctions from 2002 and 2007 could explain reductions in the incarceration of women at this time, however, there is insufficient data or research to either confirm or deny the voracity of this assumption.

The limited data and literature does suggest, albeit tentatively, that Thai women may have been disadvantaged by the 'war on drugs'. Thai prison data reported for 2008 shows that over $85 \%$ of women in prison were incarcerated for a drug offence, compared with only $56 \%$ of men (Kittayarak 2010, pp. 154). More recently, Thai researchers have argued that the "government's notion of a war on drugs has done little to solve the actual problem and has led instead to a larger number of women being jailed for small-time trafficking and consumption" (Havanond cited in Rojanaphruk 2013). Many Thai women are for example being given "long sentences for drugs found in their homes, when in reality the drugs may have belonged to their husband or boyfriend" and women are also allegedly being "lured into selling what they had at hand for personal consumption to undercover police" (Havanond cited in Rojanaphruk 2013).

Similarly, in Cambodia, it has been reported that upward trends in the incarceration of women is due to "a continued increase in drug-related arrests" (Cambodian League for the Promotion and Defence of Human Rights 2013a). Recent 'crackdowns' on drug trafficking in Cambodia have resulted in women "working at the low level of the drug trade" being seen as "easy targets for arrest, while men at the higher levels of the trade so often go unpunished" 
(Cambodian League for the Promotion and Defence of Human Rights 2013b). In 2007, 14\% of the incarcerated Cambodian women were 'doing time' for drug trafficking compared with $2.5 \%$ of men (Cambodian League for the Promotion and Defence of Human Rights 2009, pp.8). Comparable to the 'war on drugs', Cambodia's campaign against human trafficking may be another contributing factor in the growth of women's incarceration.

In 1996, anti-trafficking legislation was enacted in Cambodia that proscribed penalties as severe as those given to premeditated murder (Bouhours, Broadhurst and Keo 2012, pp. 1). In an ironic twist - the very purpose of the legislation was to protect women and children women have been the 'hardest hit' by the new law. In 2007, 31\% of all Cambodian prison inmates were women, many of whom had their children in prison with them, were incarcerated for human trafficking offences compared with only $2.5 \%$ of men (Cambodian League for the Promotion and Defence of Human Rights 2009, p. 8; Cambodian League for the Promotion and Defence of Human Rights). Furthermore, while only $3.5 \%$ of all Cambodian inmates were incarcerated for human trafficking in $2007,80 \%$ of these prisoners were women (Bouhours, Broadhurst and Keo 2012, pp. 8).

Research undertaken by Bouhours, Broadhurst and Keo's (2012, pp. 11) on 85 people convicted of human trafficking in Cambodia, revealed gender based disparities operating at the level of sentencing with women receiving significantly longer prison terms than men (on average 13.5 and 10.6 years respectively). The prison terms given ranged from two to 27 years. Nearly one-third of the men $(32.5 \%)$ received sentences shorter than ten years with only $5 \%$ being sentenced to over 15 years. For women, the pattern was the opposite with $11.6 \%$ receiving prison sentences of two to nine years and $23.3 \%$ for 15 years or longer (Bouhours, Broadhurst and Keo, 2012, pp. 11). In addition measures of socio 
advantage/disadvantage (including education, ethnicity and occupation) showed that offenders defined as more "destitute" received longer terms of incarceration and women were more likely than men to fall within this category. Bouhours, Broadhurst and Keo (2012, pp. 11) conclude:

This could suggest discriminatory practices by the [criminal justice system] against women or at least against the most destitute defendants, as women were also significantly more likely than men to be destitute. Bribing police or judges was a way of avoiding arrest or reducing one's sentence, and the most destitute defendants were the ones least able to pay a bribe....factors such as the offender's sex, education, ethnicity, and occupation point to a [criminal justice system bias] against the most powerless.

Recall that substantial increases in the imprisonment of women in Malaysia occurred after 2002. As with Thailand and Cambodia, changes in Malaysian government policy at this time suggest a possible explanation for this upward trend. In an attempt to curb 'irregular' or 'undocumented' migration the Malaysian government made legislative changes to the Immigration Act 1959/63 in 2002 that included stringent punishments for those entering and staying in the country illegally. For example, under the revised Act, women illegally entering or staying in Malaysia could be fined up to a maximum of RM10,000 or sentenced to custodial terms not exceeding five years, or both (Kanapathy 2008; Santhiago 2005). While imprisonment data by sex and offence over time could not be found, research undertaken by Teh (2006) showed that Malaysian women's prison populations are characterised by a high proportion of foreign nationals, the majority of which are imprisoned for immigration offences. Of the 422 women prisoners included in her study, Teh (2006: 48) found that over half $(52 \%)$ were foreigners. Immigration offences, such as "having no work permit, entering Malaysia illegally without a visa and having no passport were the most common offences that foreign female prisoners [were] likely to be charged with [81\%]”.

\section{Summary and Conclusion}


Women in prison are often referred to as the 'invisible' and 'forgotten' population constituting only a small number of those incarcerated globally. Nonetheless, over the last few decades, data from western nations show rapid increases in women's incarceration which has led to extensive discussion, analyses and scholarly debate.

The purpose of the current paper was to initiate a dialogue between variously regional criminologies by describing and comparing patterns and trends in the imprisonment of women across eight South East Asian countries, namely, Thailand, Vietnam, the Philippines, Myanmar, Indonesia, Malaysia Cambodia and Singapore. Results showed that over the last couple of decades there have been significant increases in the number, rate and proportion of women imprisoned. There has also been a general narrowing in female to male rate ratios. By and large patterns of women's incarceration parallel those for men but growth generally outstripped men in every country, aside from Myanmar.

The countries 'stacked up' differently based on the measures used to compare them. In Thailand women were more likely to find themselves imprisoned than elsewhere but measures of growth were at the lower end of the scale. Vietnam and Singapore were both characterised by measures of high imprisonment and growth. Indonesia and Cambodia had relatively low incarceration but high growth. Myanmar ranked highly on measures of women's imprisonment but recorded minimal growth. Compared to the other nations measures of the imprisonment of women in Malaysia were more positive, characterised by low imprisonment and minimal growth.

Given the limited nature of the extant statistics and research concerning the imprisonment of women in South East Asia this paper has attempted to engender further discussion by 
focussing on three very particular - and very pertinent - possibilities gleaned from current knowledge in the South East Asian region. Namely, from the limited information available in Thailand, Cambodia and Malaysia, that policy changes alongside shifting criminal justice system responses to particular types of crime could perhaps be having a disproportionate impact on women: the 'war on drugs' (in Thailand and Cambodia), punitive responses to human trafficking (in Cambodia), stringent immigration law (in Malaysia).

There is a pressing need for research to explore how prisons in South East Asia are being used for women. In particular, we need to know the types of offences that are driving upward trends in incarceration and the extent to which prison growth is being determined by legislation, policy and criminal justice system practices. Why are women being arrested, remanded and sentenced to prison for certain crimes? How does this compare with men and do these differences vary between countries and across time (McIvor 2010, pp. 564)? To answer these questions not only requires country-specific prison studies but also coordinated cross-regional data collection, dissemination and research effort based on the deliberate fostering of mutually coordinated projects between regional actors. 


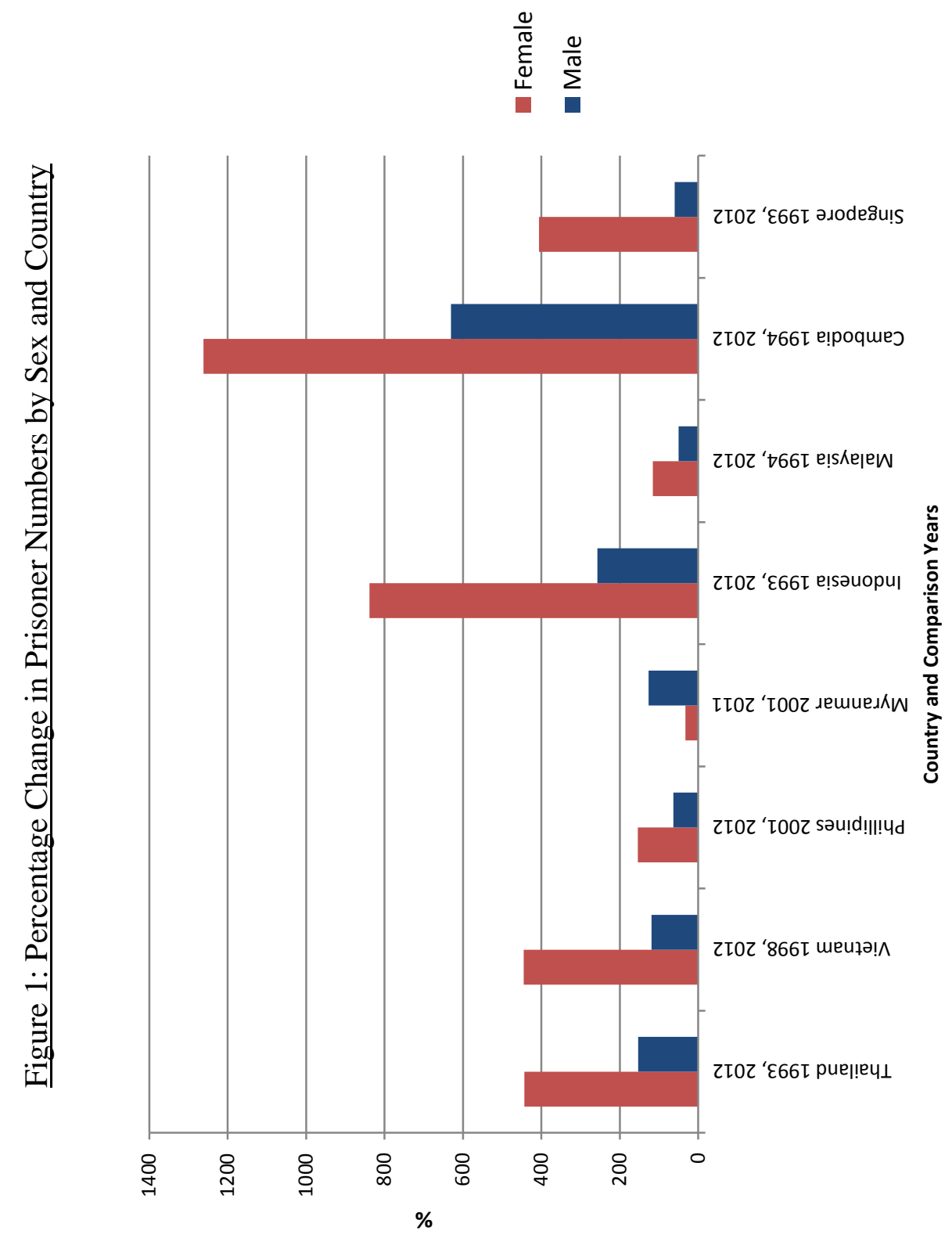



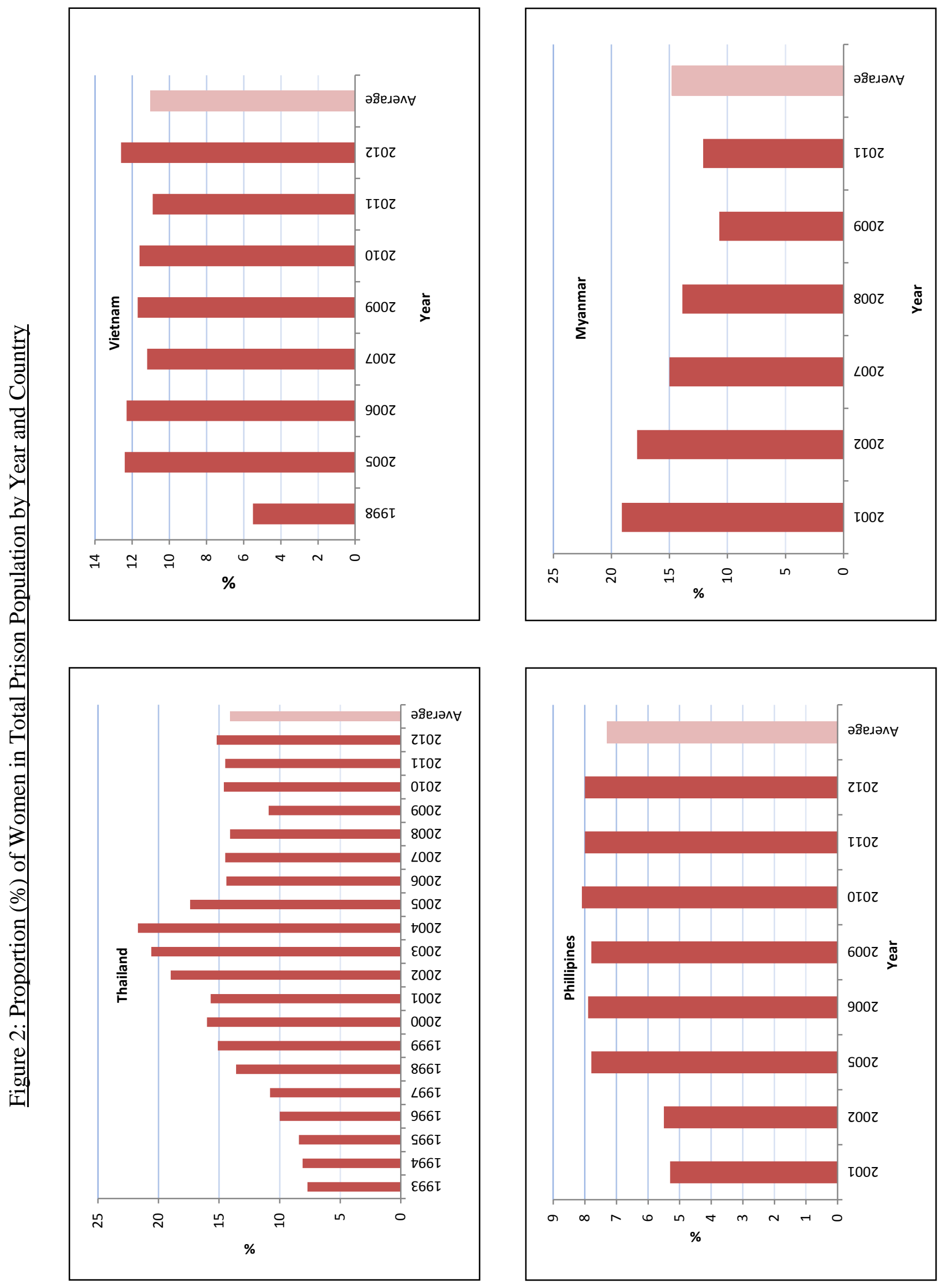

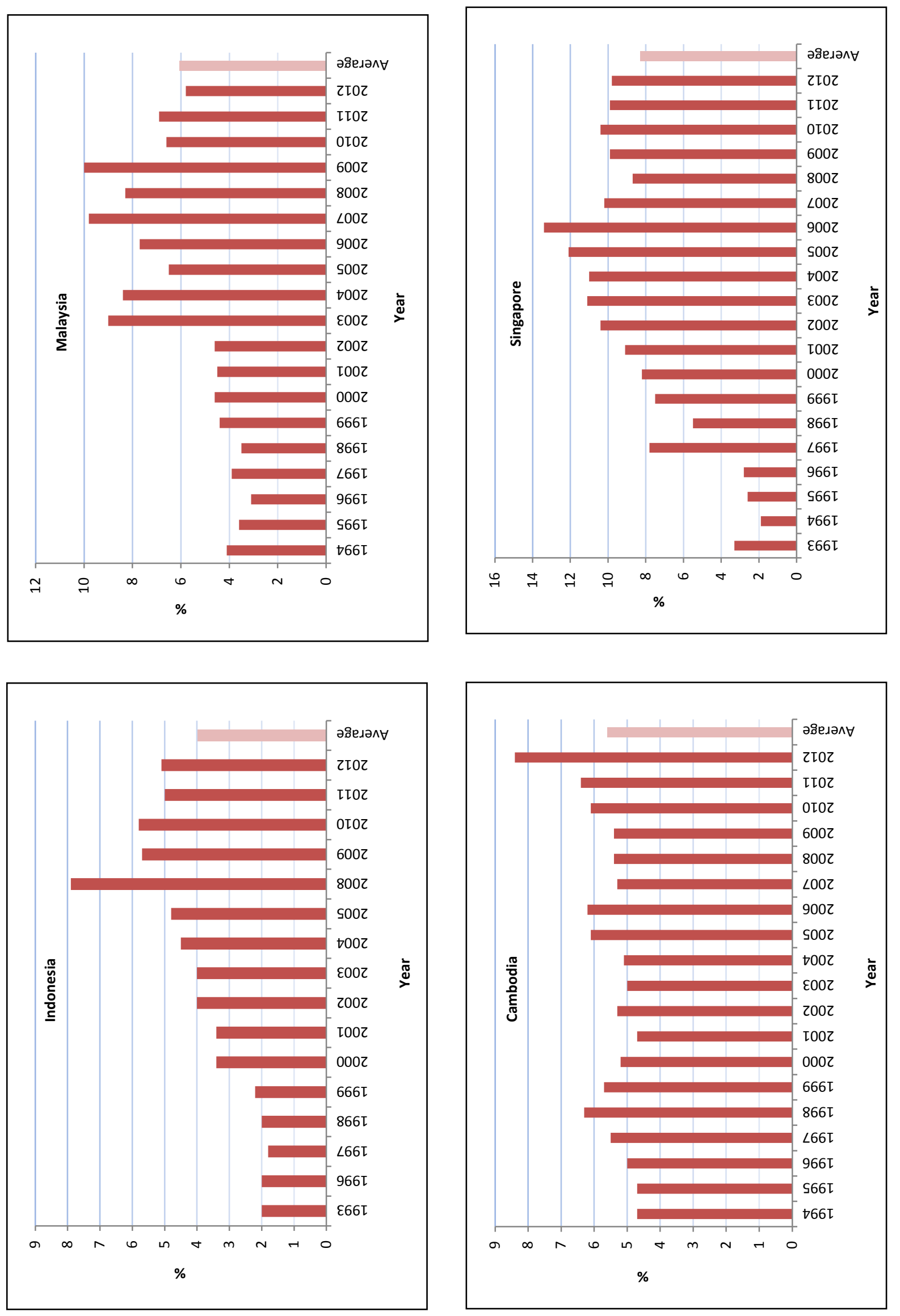

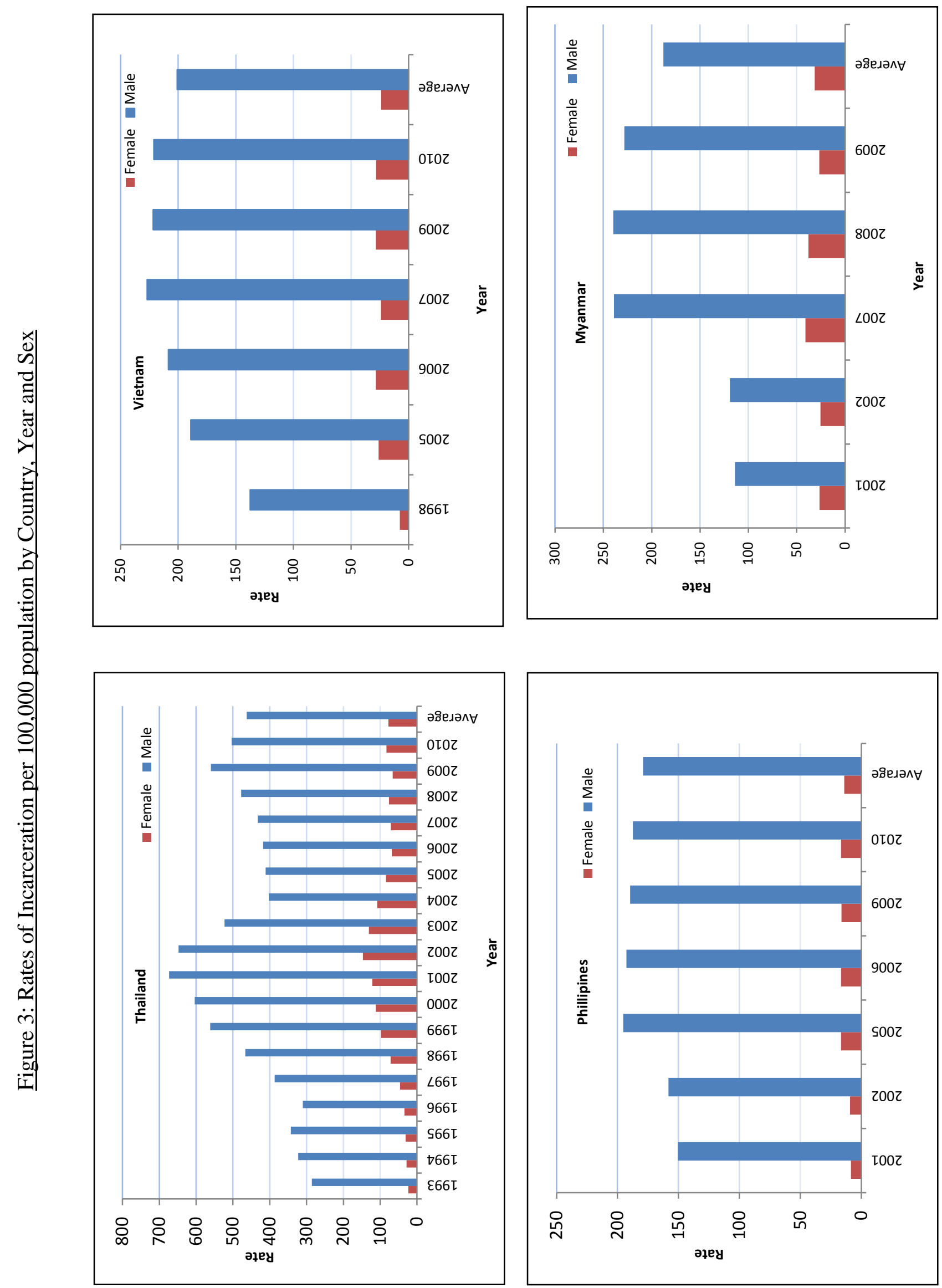


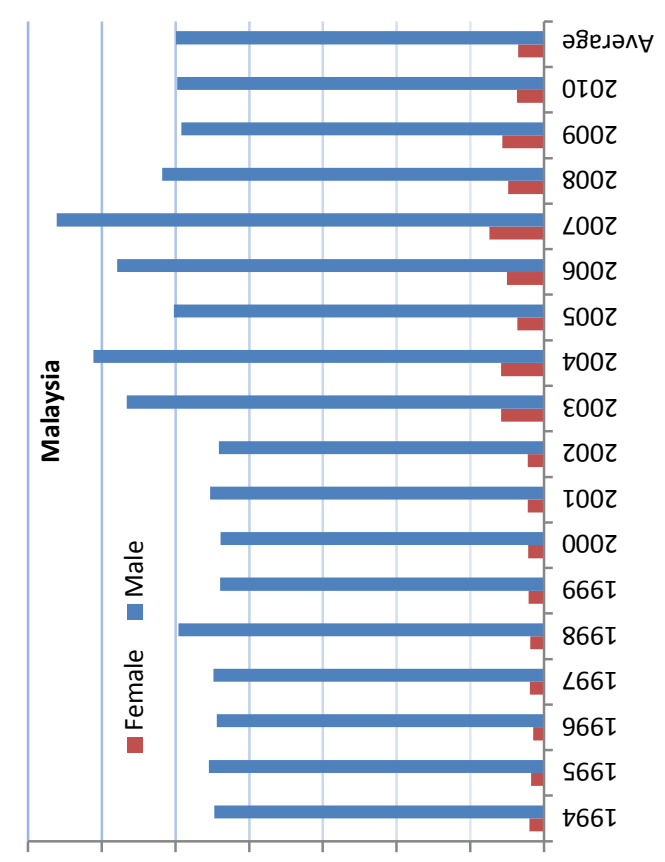

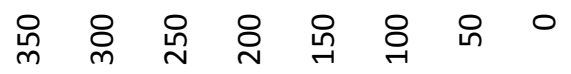
әาеу

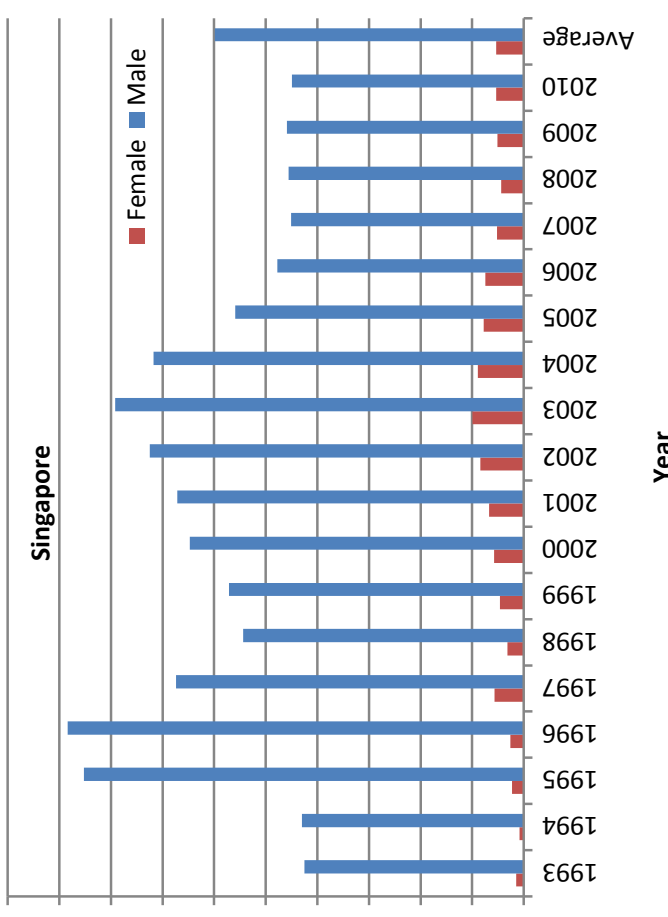

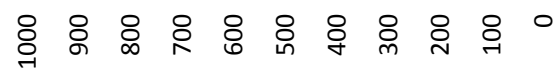
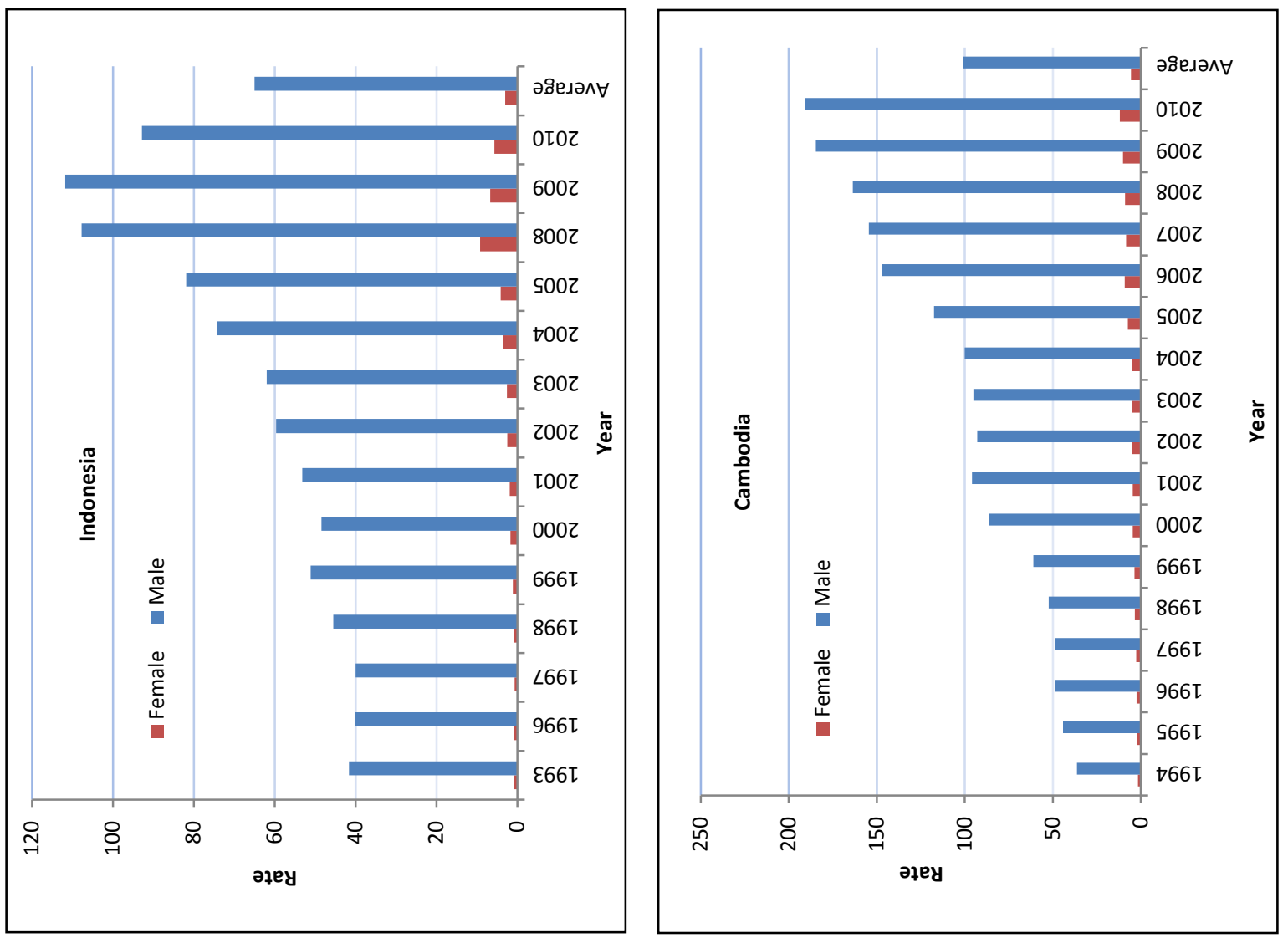


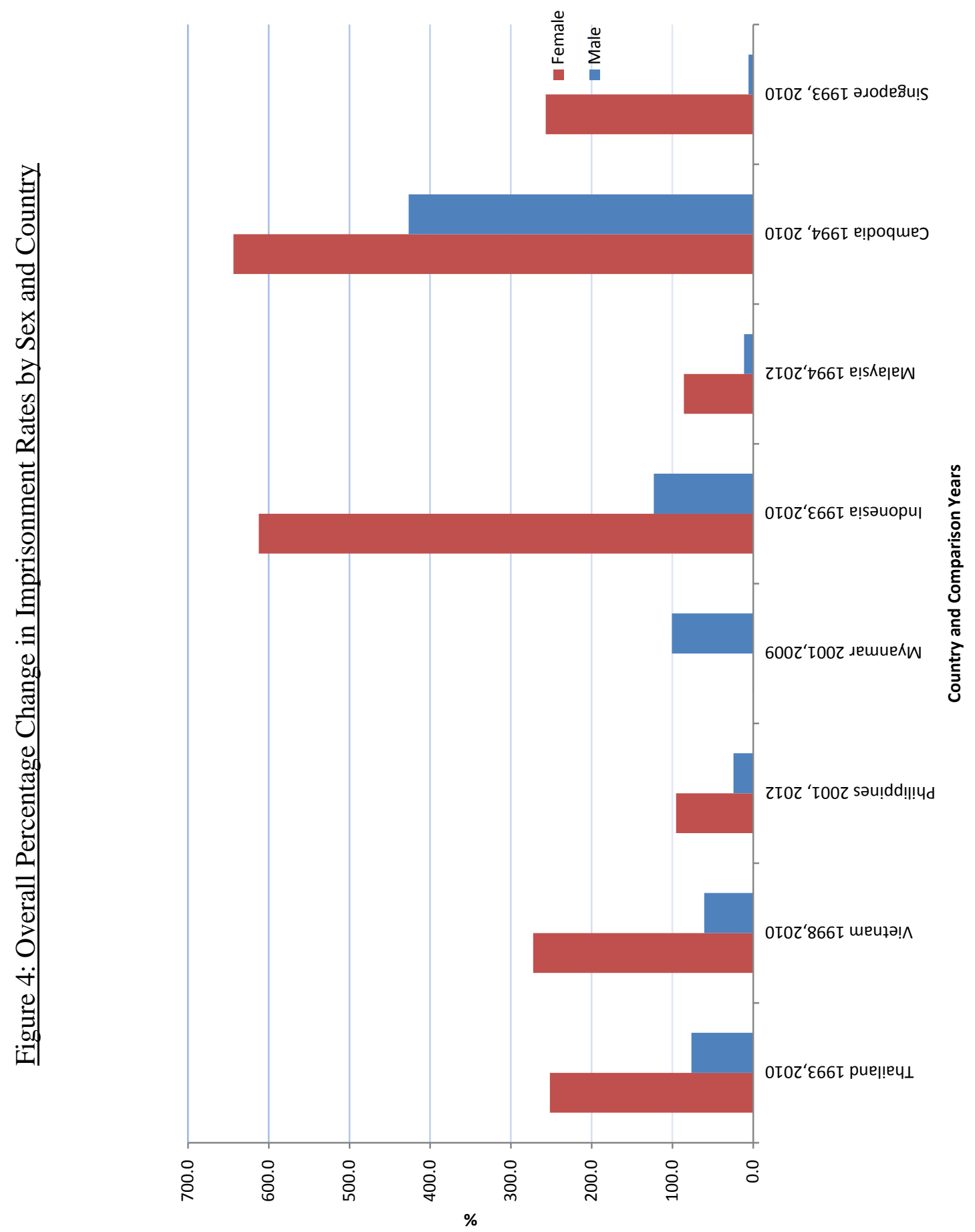




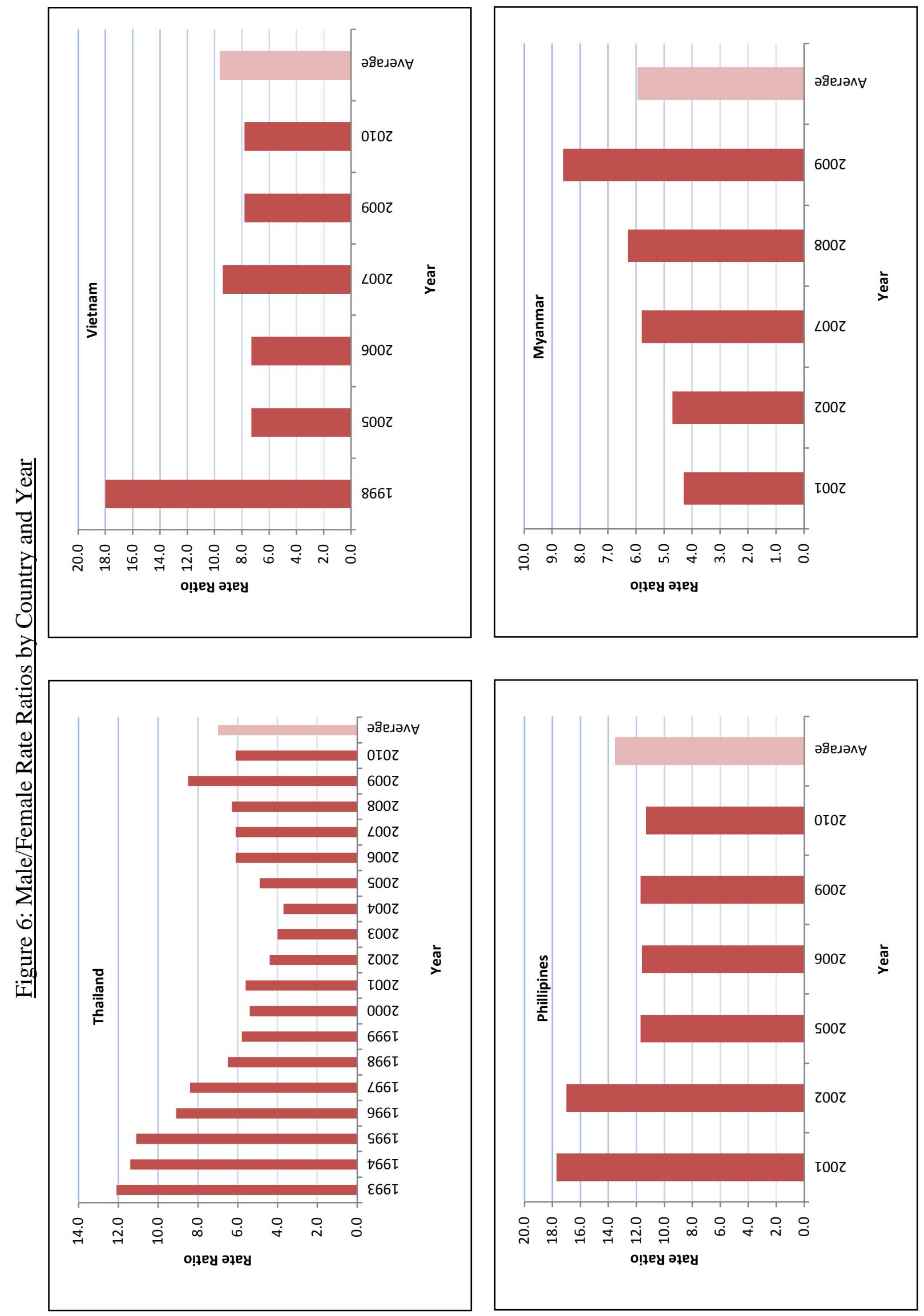



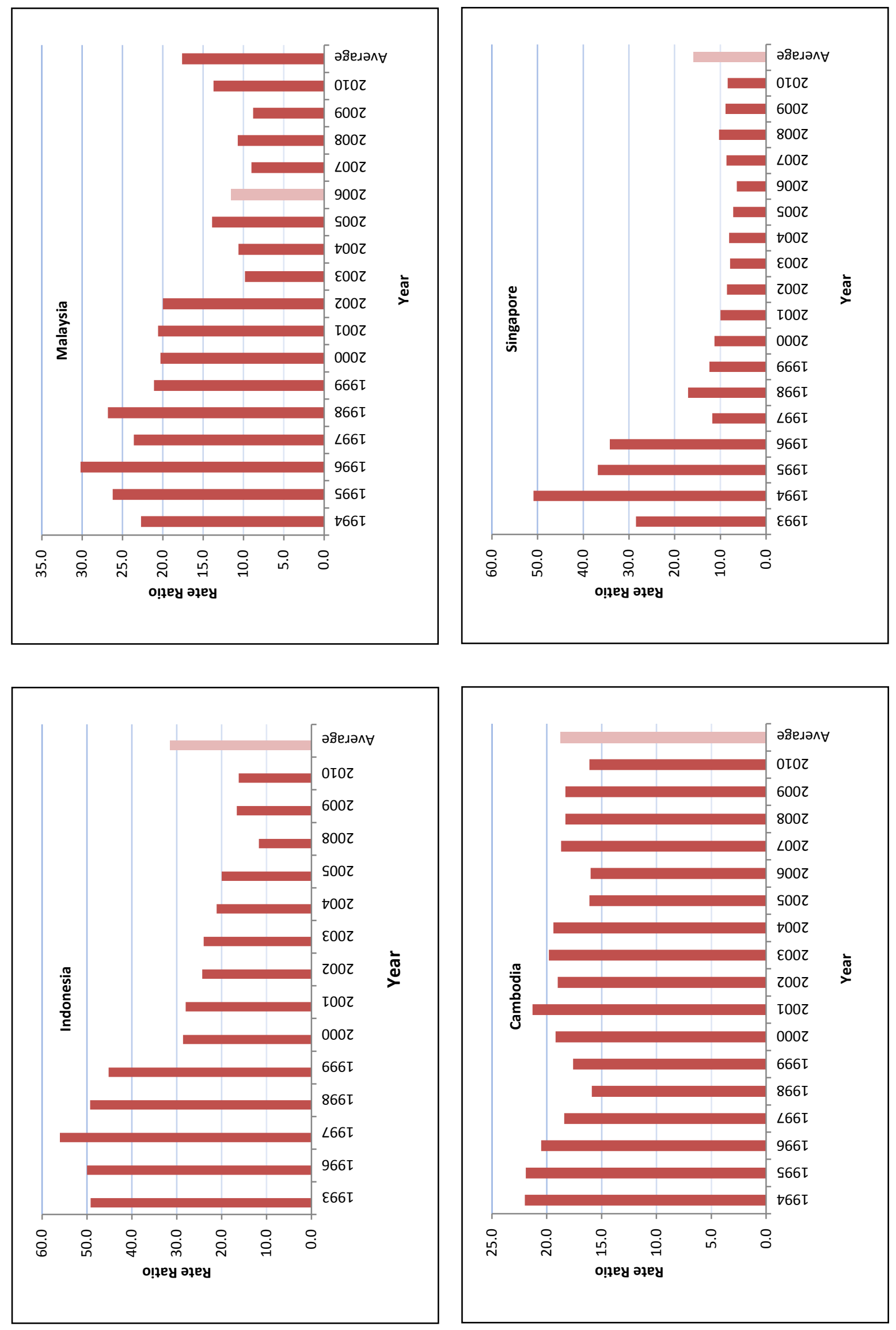


\begin{tabular}{|c|c|c|c|c|c|c|c|c|c|c|}
\hline \multirow{4}{*}{ 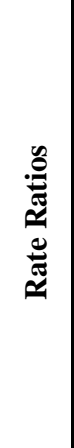 } & \multirow{2}{*}{ 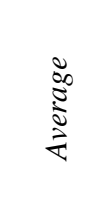 } & 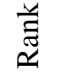 & $N$ & $m$ & $\nabla$ & - & $\infty$ & $r$ & 0 & in \\
\hline & & $\begin{array}{l}\stackrel{̊}{\pi} \\
\simeq\end{array}$ & $\stackrel{\circ}{\stackrel{2}{2}}$ & $\stackrel{0}{\circ}$ & $\begin{array}{l}n \\
m \\
-1\end{array}$ & in & $\frac{\dot{m}}{m}$ & 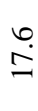 & $\stackrel{\sim}{\infty}$ & $\stackrel{0}{\dot{\theta}}$ \\
\hline & \multirow{2}{*}{ 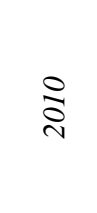 } & $\begin{array}{l}\text { है } \\
\text { こ }\end{array}$ & - & 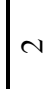 & in & $\nabla$ & $1-$ & 6 & $\infty$ & $m$ \\
\hline & & $\begin{array}{l}\stackrel{\bigcirc}{\pi ̈} \\
\simeq\end{array}$ & $\overline{6}$ & $\stackrel{\infty}{\sim}$ & $\stackrel{?}{=}$ & 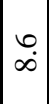 & ְֶ. & $\stackrel{\sim}{\vec{g}}$ & $\underset{6}{6}$ & $\stackrel{+}{\infty}$ \\
\hline \multirow{8}{*}{ 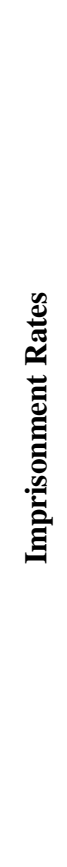 } & \multirow{2}{*}{ 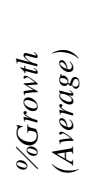 } & $\begin{array}{l}\text { है } \\
\text { こ }\end{array}$ & $r$ & - & $m$ & $\infty$ & $\sim$ & 6 & in & + \\
\hline & & $0^{\circ}$ & $\vec{a}$ & $\begin{array}{l}\infty \\
\dot{8}\end{array}$ & 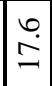 & in & $\vec{\sim}$ & $=$ & 竎 & \begin{tabular}{l}
$n$ \\
\hdashline \\
\hdashline
\end{tabular} \\
\hline & & $\begin{array}{l}\text { है } \\
\simeq\end{array}$ & in & $m$ & 0 & $\infty$ & $N$ & r & - & $\nabla$ \\
\hline & & $b^{\circ}$ & तิ & $\stackrel{\Re}{\sim}$ & $\begin{array}{l}m \\
2 \\
2\end{array}$ & $\stackrel{\infty}{\circ}$ & $\frac{m}{6}$ & $\vec{\infty}$ & 过 & $\hat{\sim}$ \\
\hline & \multirow{2}{*}{ 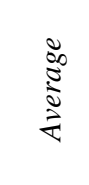 } & 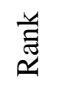 & - & t & 0 & $m$ & $\infty$ & in & r & 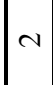 \\
\hline & & $\begin{array}{l}\stackrel{0}{\pi} \\
\approx\end{array}$ & $\stackrel{\stackrel{ }{\curvearrowright}}{\circ}$ & $\mid \begin{array}{l}\infty \\
\ddot{\lambda}\end{array}$ & \pm & $\frac{n}{m}$ & $m$ & $\stackrel{+}{\stackrel{ \pm}{=}}$ & in & $\mid \begin{array}{l}\tilde{y} \\
\tilde{n}\end{array}$ \\
\hline & \multirow{2}{*}{ 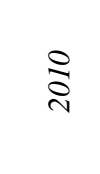 } & 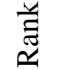 & - & $m$ & 0 & + & $\infty$ & in & r & $\sim$ \\
\hline & & $\frac{\mathscr{N}}{\approx}$ & $\infty$ & $\begin{array}{l}m \\
\infty \\
\infty\end{array}$ & $\begin{array}{l}0 \\
0 \\
0\end{array}$ & $\hat{i}$ & is & $\underset{\infty}{2}$ & $\stackrel{9}{=}$ & $\begin{array}{l}\tilde{n} \\
\tilde{n}\end{array}$ \\
\hline \multirow{4}{*}{ 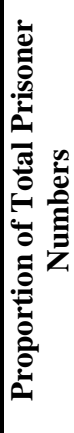 } & & 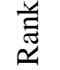 & N & $m$ & in & - & $\infty$ & 0 & r & + \\
\hline & & $\Delta^{\circ}$ & $\overrightarrow{ \pm}$ & $\stackrel{\circ}{\Xi}$ & $\stackrel{m}{r}$ & $\begin{array}{l}\infty \\
\dot{\Xi}\end{array}$ & $\stackrel{\circ}{+}$ & $\overrightarrow{6}$ & 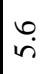 & $\underset{\infty}{\infty}$ \\
\hline & & 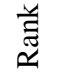 & - & N & 0 & $m$ & $\infty$ & $1-$ & in & + \\
\hline & & $\Delta^{\circ}$ & 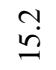 & $\begin{array}{l}0 \\
\text { I }\end{array}$ & $\underset{\infty}{0}$ & $\overline{\mathrm{I}}$ & $\overrightarrow{i n}$ & 文 & $\underset{\infty}{+}$ & $\stackrel{\infty}{\infty}$ \\
\hline \multirow{4}{*}{ 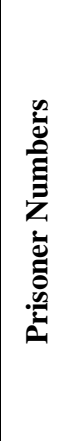 } & \multirow{2}{*}{ 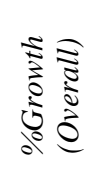 } & 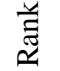 & $\nabla$ & $m$ & 0 & $\infty$ & $\mathrm{N}$ & $1-$ & - & in \\
\hline & & $\therefore$ & $\stackrel{\stackrel{\sim}{*}}{\stackrel{f}{f}}$ & 年 & 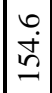 & $\begin{array}{l}0 \\
\dot{m} \\
\end{array}$ & $\begin{array}{l}\infty \\
\infty \\
\infty \\
\infty\end{array}$ & ?ִ & ?. & 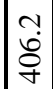 \\
\hline & & $\begin{array}{l}\text { चै } \\
\widetilde{\Xi}\end{array}$ & - & $\sim$ & $n$ & + & in & 0 & $r$ & $\infty$ \\
\hline & $\stackrel{\sim}{\sim}$ & $\begin{array}{l}\overline{\bar{D}} \\
\stackrel{\Xi}{\Xi} \\
\bar{z}\end{array}$ & $\begin{array}{l}\stackrel{2}{\text {. }} \\
\stackrel{m}{0}\end{array}$ & 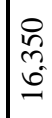 & $\mid \begin{array}{l}0 \\
0 \\
\vdots \\
\infty \\
\infty\end{array}$ & $\mid \begin{array}{c}\S \\
\varnothing \\
\infty\end{array}$ & \begin{tabular}{l}
$\infty$ \\
0 \\
0 \\
\hdashline
\end{tabular} & $\stackrel{m}{=}$ & İ & $\stackrel{尺}{\stackrel{\overbrace{}}{-}}$ \\
\hline & & & 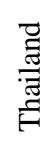 & 志 & 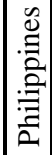 & 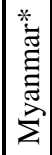 & 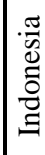 & 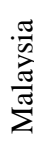 & 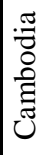 & 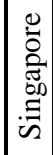 \\
\hline
\end{tabular}




\section{References}

Australian Bureau of Statistics. (2013). Prisoners in Australia, 2012. Canberra: Australian Bureau of Statistics.

Belknap, J. (1996). The invisible woman: gender, crime and justice. Belmont: Wadsworth Publishing Company.

Bloom, B., Owen, B., \& Covington, S. (2004). Women offenders and the gendered effects of public policy. Review of Policy, 21(1), 31-47.

Bouhours, T., Broadhurst, R., Keo, C. (2012 forthcoming Annals of the American Academy of Political Science). Human Trafficking and Moral Panic in Cambodia: The Unintended Consequences of Good Intentions. Canberra: Australian National University.

Braithwaite, R.L., Treadwell, H.M., \& Arriola, K.R.J. (2005). Health disparities and incarcerated Women: a population ignored. American Journal of Public Health, 95(10), 16791681.

Britton, D.M. (2004). Feminism in criminology. In M. Chesney-Lind, \& L. Pasko (Eds.), Girls, Women and Crime: Selected Readings (pp. 61-74). California: Thousand Oaks.

Broadhurst, R., Bouhours, T., \& Keo, C. (2013). Crime and justice in Cambodia. In Liu, J., Hebenton, B., \& S. Jou (Eds.), Handbook of Asian Criminology (pp. 167-181). New York: Springer.

Bush-Baskette, S.R. (1998). The war on drugs as a war against black women. In S.L. Miller (Ed.), Crime Control and Women: Feminist Implications of Criminal Justice Policy (pp.113129). Thousand Oaks: Sage.

Cambodian League for the Promotion and Defence of Human Rights. (2013a). LICADHO Highlights Alarming Increase in Female Prisoner Population to Mark International Women's Day. http://www.licadho-cambodia.org/pressrelease.php?perm=303. Accessed 14 June 2013.

Cambodian League for the Promotion and Defence of Human Rights. (2013b). Rise in Cambodia's Women Prisoners 'Alarming'. http://www.rfa.org/english/news/cambodia/prisoners-03082013180820.html. Accessed 14 June 2013.

Cambodian League for the Promotion and Defence of Human Rights. (2010). A Review of the Condition of Mothers, Pregnant Women and Young Children in Cambodian Prisons. Phnom Penh: Cambodian League for the Promotion and Defence of Human Rights.

Cambodian League for the Promotion and Defence of Human Rights. (2009). Prison Conditions in Cambodia 2008: Women in Prison. Phnom Penh: Cambodian League for the Promotion and Defence of Human Rights.

Chesney-Lind, M. (1998). Women in prison: from partial justice to vengeful equity. Corrections Today, 60(7), 66-73.

Chesney-Lind, M., \& Pasko, L. (2004). The Female Offender: Girls, Women and Crime (2 $2^{\text {nd }}$ Edition). Thousand Oaks: Sage. 
Covington, S.S. (1998). Breaking the rules: women in prison and feminist therapy. Women and Therapy, 21(1), 141-155.

Covington, S.S., \& Bloom, B.E. (2003). Gendered justice: women in the criminal justice system. In B.E. Bloom (Ed.), Gendered Justice: Addressing Female Offenders (pp. 1-20). Durham, Carolina: Carolina Academic Press.

Green, J., \& Pranis, K. (2006). The Punitiveness Report: Hard Hit: The Growth in the Imprisonment of Women, 1977-2004. Washington: Women's Prison Association.

Fair, H. (2009). International review of women's prisons. Prison Service Journal, 184(3), 3-8.

Fletcher, B.R., Shave, L.D., \& Moon, D. (1993). Women Prisoners: A Forgotten Population. Westport: Praeger.

Gelb, K. (2003). Women in prison: why is the rate of incarceration increasing?, paper presented at Evaluation in Crime and Justice: Trends and Methods. Canberra: Australian Institute of Criminology.

Gelsthorpe, L. (2006). Counterblast: women and criminal justice: say it again, again and again. The Howard Journal, 45(4), 421-424.

Gainsborough, J. (2007). Women in prison: international problems and human rights based approaches to reform. William and Mary Journal of Women and the Law, 14, 271-304.

Greene, J., \& Pranis, K. (2006). Hard Hit: The Growth in the Imprisonment of Women, 19772004. Washington: Institute on Women and Criminal Justice.

Hartney, C. (2006). U.S. Rates of Incarceration: A Global Perspective. Washington: The National Council on Crime and Delinquency.

Hedderman, C. (2012). Empty Cells or Empty Words? Government Policy on Reducing the Number of Women Going to Prison. London: Criminal Justice Alliance.

Hedderman, C. (2004). Why are women being sentenced to custody? In G. McIvor (Ed.), Women Who Offend (pp. 82-96). London: Jessica Kingsley.

Junlakan, L.D., Boriboonthana, Y., \& A. Sangkhanate. (2013). Contemporary crime and punishment in Thailand. In Liu, J., Hebenton, B., \& S. Jou (Eds.), Handbook of Asian Criminology (pp. 309-326). New York: Springer.

Kanapathy, V. (2008). Controlling Irregular Migration the Malaysian Experience. Bangkok: International Labour Organization.

Kittayarak, K. (2010). Responding to Prison Overcrowding: Another Attempt from Thailand. Bangkok: Ministry of Justice.

Kruttschnitt, C., Gartner, R. (2003). Women's Imprisonment. In M. Tonry (Ed.), Crime and Review of Research (Volume 30) (pp. 1-81). Chicago: University of Chicago Press.

Kruttschnitt, C. (2010). The paradox of women's imprisonment. Daedalus, 139(3), 32-42.

Mauer, M., Potler, C., \& Wolf, R. (1999). Gender and Justice: Women, Drugs and Sentencing Policy. Washington: The Sentencing Project. 
McIvor, G., \& Burman, M. (2011). Understanding the Drivers of Female Imprisonment in Scotland. Glasgow/Stirling: Scottish Centre for Crime and Justice Research.

McIvor, G. (2010). Women and crime: the rise of female imprisonment in western jurisdictions. In M. Herzog-Evans (Ed.), Transnational Criminology Manual (Volume 2) (pp.553-570). Nijmegen: Wolf Publishing.

McQuaide, S., \& Ehrenreich, J.H. (1998). Women in prison: approaches to understanding the lives of a forgotten population. Affilia, 13(2), 233-246.

Morrision, B., Soboleva, N., \& Chong, Jin. (2008). Conviction and Sentencing of Offenders in New Zealand: 1997-2006. Wellington: Ministry of Justice.

Pearshouse, R. (2009). Compulsory Drug Treatment in Thailand: Observations on the Narcotic Addict Rehabilitation Act B.E. 2545 (2002). Toronto: Canadian HIV/AIDS Legal Network.

Rojanaphruk, P. (2013). War on Drug Hitting Women Hard: Study. The Nation. http://www.nationmultimedia.com/national/War-on-drugs-hitting-poor-women-hard-study$\underline{30206169 . h t m l}$

Santhiago, A. (2005). Human Smuggling, Migration and Human Rights: A Malaysian Experience. The International Council on Human Rights, Review Meeting, Geneva, 25-26 July.

Teh, T.K. (2006). Female prisoners in Malaysia. Journal of Offender Rehabilitation, 43(1), 45-64.

The Sentencing Project. (2011). Trends in U.S. Corrections. Washington: The Sentencing Project.

U.S. Department of Justice. (2010). Prisons in 2010. Washington: U.S. Department of Justice.

Walmsley, R. (2012). World Female Imprisonment List (Second Edition). London: International Centre for Prison Studies.

\section{Acknowledgments}

The author would like to thank Roy Walmsley (World Prison Brief Director, International Centre for Prison Studies) for providing the data used in this article along with the provision of comments on earlier paper drafts. She is also thankful to Jessica Jeffries, Rodney Hughes, Damian Nisbet and the anonymous reviewers for their comments and editorial skills. 


\section{Response to Reviewer}

I would like to thank the Reviewer for their subsequent comments on this paper. I agree that there are some "missing topics". As stated extensively throughout out this paper, the limited data/research/information on women's incarceration in this region is of concern and needs to be rectified. I am hopeful that, as stated by the reviewer, that my overviewing of main issues in this paper will provide "a good baseline" for further dialogue on this issue. More specifically, the Reviewer suggests that:

1. That "there are, inevitably some missing topics which would be nice to include or at least mention" (e.g. racial/ethnic breakdown, age, other "particular groups", "foreign nationals") and expresses concern re: why the World Prison Brief data was utilised. I have now included the following footnote in the paper to address these concerns:

The World Prison Brief is recognised as being a unique source of world prison population information, based on official information from national prison administrators, the government Ministries responsible for prisons and the national statistical offices. It is widely used by international bodies (including the United Nations), governments, prison authorities, academics and other criminal justice experts. The collation of prison data into a reliable data source provides a unique opportunity to assess differences in the levels of imprisonment across the world, including South East Asia. The World Prison Brief is obviously restricted, however, by the data recorded by nation states. Thus, there is some variability in dates and data 'break downs' by gender and other potentially important factors (e.g. age, ethnicity, race, immigration status) are frequently missing or simply unavailable.

That the paper.....would be improved by a little more intellectual framing, in order to identify ways forward. Are you recommending better dissemination of stats by nation states only? Or is there need for a new kind of (feminist?) criminology in Asia? What else do we need to know and how would you set about looking into it?

I feel that I have addressed these concerns in the final paragraph of this paper but have made minor changes to better express this:

There is a pressing need for research to explore how prisons in South East Asia are being used for women. In particular, we need to know the types of offences that are driving upward trends in incarceration and the extent to which prison growth is being determined by legislation, policy and criminal justice system practices. Why are women being arrested, remanded and sentenced to prison for certain crimes? How does this compare with men and do these differences vary between countries and across time (McIvor 2010, pp. 564)? To answer these questions not only requires country-specific prison studies but also coordinated cross-regional data collection, dissemination and research effort based on the deliberate fostering of mutually coordinated projects between regional actors.

The issue of whether or not Asia requires a new kind of feminist criminology is beyond the scope of this paper. This is a question that needs to be raised and discussed within Asian Criminology itself. To address it would require the mapping feminist thought within Asian criminology i.e. where have has it been and where does it need go? As a western feminist scholar based in Australia, I do not believe I am in the position to comment on the development of an Asian feminist criminology. 